\title{
Christianity: Queer Pasts, Queer Futures?
}

\author{
Cristianismo: Passado Queer, Futuro Queer?
}

Lisa Isherwood*

\begin{abstract}
This paper asks whether Christianity has always been queer, is the very nature of it beyond what one might expect from reality? Does the core of Christianity destabilise the categories by which subsequent Christian leaders have created doctrine, developed ethics and controlled the faithful? Is this queer core located in the very notion of incarnation itself, an event that truly changes all we thought we knew about the nature of materiality? The paper is not attempting to find a queer past in order to justify a queer present and solidify a queer future but rather to suggest that fluidity, rupture and unexpected outcomes should be at the heart of the Christian enterprise. It also follows that if the categories which have been used to exclude are themselves queered then Christianity becomes a far more inclusive way of living. The paper also asks whether the very notion of monotheism itself is a barrier to what may be understood as the fluid volatile core of incarnational religion. What does the queer theologian do with the ONE?
\end{abstract}

Keywords: queer theology; incarnation; monotheism; Thecla; cross dressing; Bi-Christ

\section{Resumo}

O presente artigo indaga o seguinte: se o cristianismo sempre foi Queer, a sua natureza está para além do que se poderia esperar da realidade? O núcleo essencial do cristianismo desestabilizaria as categorias pelas quais os líderes cristãos subsequentes criaram sua doutrina, desenvolveram sua ética e assim controlaram os fiéis? Estaria a essência Queer situada na própria noção de encarnação, um evento que que de fato mudaria tudo o que nós pensávamos que sabíamos sobre a natureza da materialidade? 0 artigo não pretende encontrar um passado Queer para poder justificar um presente Queer e então solidificar um future Queer mas sugerir que a fluidez, a ruptura e os resultados inesperados encontramse no centro da vivência crista. Podemos inferir o seguinte: se as categorias que têm sido utilizadas para excluir são, elas mesmas Queers, iso faz com que o cristianismo possa se tornar, ele mesmo, uma forma mais inclusiva de se viver. $\mathrm{O}$ artigo também pergunta se a própria noção de monoteísmo é uma barreira para o que pode ser entendido como o núcleo volátil e fluido de uma religião de encarnacionista. Como o teólogo Queer pode lidar com o Uno?

Palavras chaves: theologia queer; encarnação; monoteismo; Thecla; travestismo; Cristo-Bi.

Article received on May 15, 2015, and aprroved on September 27, 2015.

* PhD in Theology, Professor of Feminist Liberation Theologies, Director of the Institute for Theological Partnerships, University of Winchester, UK. Co-founder and Director of the Britain and Ireland School of Feminist Theology, FRSA. Country of origin: UK. E mail: lisa.isherwood@winchester.ac.uk

Horizonte, Belo Horizonte, v. 13, n. 39, p.1345-1374, July/Sept. 2015 - ISSN 2175-5841 


\section{Introduction}

Despite the title of the paper I am not attempting to find a fixed queer past in Christianity in order to move towards a queer future. Rather I am asking whether the very incarnational nature of Christianity alters our perceptions of materiality and the way we understand reality. Perhaps a religion with incarnation at its heart should never have become rigid with a fixed set of rules and ways of being such as Christianity has throughout its history endeavoured to inflict on its followers. Rather, the very disruption of materiality that incarnation demonstrates should place us in a more fluid understanding of the world and the divine and open us to unexpected ways of being, both human and divine. Such a way of being would necessarily bring monotheism under scrutiny and ask if a truly incarnational religion can function fully and in a life giving way with such a concept within it.

\section{Defining the terms}

Before attempting to examine the questions it is necessary to define my terms. Queer theology is a new discipline and with this newness comes certain flexibility about the term itself - as we will see that is not entirely unexpected. Queering is a method by which we expose and engage with the untidy edges, the bits that do not fit a neat system, such as for example systematic theology!. Through trespassing and transgressing, through mining submerged knowledges queering attempts to change the way we see and act. It is a refusal to be normalised into oblivion through the deadening systems of a binary opposite world, it is a contradiction and a fluid revolution.

It is believed that the word queer comes from Indo European roots which mean across, to transverse- to move to and even to be relational and strange. Further, it suggest we have nothing fixed and are always open to possibilities. So at first glance not something that Western Christian theology would touch with a 
barge pole. However to give it its due theology has always been contextual, and it has always depended on a theoretical framework of interpretation of the world. The fact is that theology is not enough; in itself it is insufficient as a discipline to provide us with a basis for explaining critically the reality in which we live. Traditionally in the West, the philosophy of Plato and Aristotle, the latter mediated through Aquinas, has provided theology not only with a theoretical framework of interpretation but also with a particular kind of questioning. Had that been Chinese or African philosophy in dialogue with theology, rather than Greek, we would have a different style of doing theology and a distinctive set of questions and problematics to discuss than the ones we have inherited. It is curious that a system so unrelated to its Jewish origins has set the agenda for traditional Christian thinking, more than that has actually set the constraints on what it may think.

It is true that the theoretical framework of interpretation which theology uses has varied in time and although many traditionalists are reluctant to admit it new awakenings of consciousness, both secular and religious have challenged previously held theological orthodoxies. Such is the case with queer theory as a radical theoretical field which has provided a style and a questioning that crucially destabilises theological praxis. From the urban protests of the Carnival against Capitalism to the reflections on sexuality at the margins, queer theory has deregulated the binary myths of the subjects of theology, and in doing that, it has de-regulated our representations of God. Therefore, queer theory works as a new "mediator science" in radical theologies. Just as Liberation Theology was seen as the eruption of the poor in theology so queer theory has facilitated the eruption of the ultimately marginalized in Christianity and has begun to give voice to both individuals and organisations at the margins.

Queer should then no longer be understood as a noun that marks an identity we have been taught to despise but rather as a verb that destabilises any claim to identity. It has come to symbolise the moving around or crossing of boundaries in 
order to get another eye on the tradition. The so called straight mind is one that isdivided within itself since it has to cut out so much that is real in order to maintain the illusion of unity, a unity ironically based in dualism, the hetero of the straight mind. The queer mind lives with the opposites and indeed embraces the contradictions as a way of moving more deeply into an understanding of what may be real. It is then an extremely useful hermeneutical device with which to subvert the rigid doctrinal discourses of Christianity and to release people from their worst excesses. Queer Theology then is a movement, and an alliance of people who question the construction of theology. Queer theology takes seriously the queer project of deconstructing heterosexual epistemology and presuppositions in theology, but also unveiling the different, the suppressed face of God amidst it. It is not only that theology has been traditionally obsessed with ordering sexuality, but much of theology has developed forms of sexual orderings into doctrinal reflections or even the reading of the scriptures (ALTHAUS-REID; ISHERWOOD, 2004).

Queer theologians write the divine differently because the focus of reflection in this theology is different and how people dare to write is different. As a subversive force, queer theology focuses on theological closets, in what has not been said or has been hidden. Its strategy is to read theology dismantling dualist readings and oppositions. It may read the Scriptures in a specific sexual way which departs from heteronormativity; it identifies moments of sexual resistance in church traditions; or even alternative church traditions and finds neglected areas for attention in theological discussions. Queer theologians plunge into flesh in its unrefined fullness in order to embrace and be embraced by the divine. Bodies tell very complex and challenging stories and these now become the stuff of the salvific tale. We are all too well aware of how we have constructed bodies within boundaries that could never contain them but have at times distorted and mutilated them. Queer theology challenges the boundaries and wishes to propel us into a much wider paradise, because incarnation will not be confined. Queer theology asks us to take lives, including that of Jesus of Nazareth, in the raw and 
examine how we between us embody the transformative and spiralling reality of incarnation and the redemptive space we strive for. We are challenged to move beyond metaphysics and the comfortable world that they create. Queer theology with its post-modern roots asks us to distrust any master narrative and there is no bigger one than metaphysics -it fixes everything in its place and gives a place to everything.

\section{Feminist Liberation Theology}

I need to come clean at the start this will not be an unbiased examination of the question- I am a feminist liberation theologian who finds queer theory/theology helps with the questions posed and the gaps exposed by feminist liberation theology. Queer theology in my view can engage well with feminist theology and its untidy edges since queer theory enjoys engaging with the bits that do not fit the system. Through trespassing and transgressing, through mining submerged knowledges queering attempts to change the way we see and act. It is a refusal to be normalised into oblivion through the deadening systems of a binary opposite world, it is a contradiction and a fluid revolution. To my mind it is a way of expressing theologically that can expand and make more glorious our incarnational being. Further, of course, it takes on and expands that very useful feminist tool- imagination. Unconstrained by convention it allows for exploration of all the edgy questions, the dark corners of theology and human existence and does not begin with expectations of correct answers. Not having to find creedal answers is in itself frightening and freeing. Many have spoken of the courage it takes to carry out queer enquiry and this does not seem to be overstated.

In order to address the title of the paper I hope to present a somewhat destabilised Christian past in order to move towards a totally unstable, open and challenging Christian future. So having explained how I see queer theology I need to explain how I understand Christianity which may shed light on how I read the 
past and how I move within a future I think possible. Of course, my understanding is indebted to many of my feminist sisters. Christianity is rooted in the belief that the life and death of Jesus o Nazareth has redemptive significance for all humanity for all time. Further, that reflection on that life and death allows the creation of doctrine and ethics that also stand for all time. Many need to believe that this means doctrine, ethics and church community have been and need to be static, stuck in truth filled beginnings which are carried through to the end. However, an honest look at church history shows that change has happened, with what was once orthodoxy becoming seen as heresy and vice versa. Feminist theology has engaged in this ongoing conversation with Christian 'orthodoxy' and has become adept at developing reading strategies using feminist theory, post-colonialism, and many postmodern stances which challenge much theology still rooted in and interpreted through the lens of Greek philosophy. These alternate strategies have enabled women's lived experience to be placed front and centre in reflections on theology and ethics. This has of course led to new meaning emerging but most importantly it has also highlighted the gaps- that is to say every inch/breathing space has not been filled by new feminist orthodoxies but rather feminist theology has left untidy edges, which it is happy to live with, since feminist theologies do not believe that the divine suffers from an obsessive compulsion to control - after all a god who incarnates in flesh and blood surely cannot expect that everything will remain the same, all neat, tidy and in place.

I understand Christianity to be a story rooted in incarnation but an incarnation that is erotic, sensuous and powerful; one that urges us forward to relationality and flourishing, to life in abundance. It is, for me, the glorious abandonment of the divine into flesh and the passionate dance of the human/divine that ensues. Incarnation tells us that our bodies are our homes, that is to say our divine/human dwelling places, therefore our journey is home, to the fullness of our incarnation, the co-redemptive, co-creative reality of our fleshy 
heaven ${ }^{1}$. Perhaps we can argue that theology that has incarnation at its heart is queer indeed, what else so fundamentally challenges the nature of human and divine identity. That the divine immersed itself in flesh and that flesh is now divine - God became man[ as the Church Fathers tell us] so that man might become god [all too often but not what I have in mind!] is queer theology at its peak. There can be no sanitization here or something of the divine essence will be lost. Therefore the theology this assumes is not one of denial and narrow boundaries it is one of embrace and expansion that wilfully wishes to move the edges of the world in which we live. Joan Casanas reminds us that those who made an opening in, ruptured existing reality as Jesus did, want others to make it bigger, in other words the power we see in the life of Jesus is the power we are asked to embrace in order to continue the bursting forth of the divine in the every day. I believe this view of incarnation creatively and empoweringly collapses dualisms and declares Christianity to be a skin trade, a face to face mutual engagement human/divine to human/divine and even human/non-human /divine. This does not assume static Christians after all the words of the Prologue of John's Gospel declare a God who pitched his tent, a moveable dwelling, one fit for the walks we all take, one that expands and changes shape with the winds of change. It was this incarnation who became god in community/God in society. We see how the incarnate Jesus walked with and was affected by diverse groups of people. Christians then may not project the abject or consume difference but should rather be open to change through the adventure of expanding incarnation. It goes without saying then that politics is not an added extra for people of incarnate faith but rather radical, countercultural politics is the skin we put on as we spiral in our incarnate living.

I think it is becoming clear that for me Christianity is about the flesh and blood reality of people's lives in which our potential as co-creators and coredeemers is lived out, so it also follows that all manner of embodiment and

\footnotetext{
${ }^{1}$ Those who have read Liberating Christ will understand that this is far from the individualistic statement that it appears to be, it is rather a cry for heaven on earth, a cry both biblical and doctrinal. It is a call for the radical nature of incarnation to be taken seriously, to be lived, to be put on. I have my critics!
} 
embodied experience is a further unfolding of the divine/human reality that we live. Of course this understanding of Christianity has also made me very suspicious about things we take as 'normal' in theology and society as hearing about the lives of people has never given me a clear idea of what normal in reality might be. It seems that norms are easy conveniences for those who like surveys and statistics but they are not for those who are lovers of God in the flesh in all its complexity. But in rejecting Christian norms are we rejecting 'truths' embedded in Christianity or simply uncovering, rediscovering or inventing useable and creative Christian pasts.

Perhaps an example of how rethinking about one group of women in our history has changed from 'norm', through feminist readings to queer may be helpful here and begin the journey to find a possible queer past.

\section{Queer Readings of the Christian Past}

There is a strong body of scholarship (MACDONALD, 1983) which suggests that the stories in the Apocryphal Acts, many of which are about women, are folktales and as such they claim to present history. Folk-tales serve two opposing purposes they stabilise society and at the same time they de-stabilise society. They can define the identity of those who are dissatisfied with society and become a source of strength for that group. What we find in many of the Christian stories are women who defy physical boundaries and so question social gender and sexual roles by their actions.

Thecla is an interesting character in this regard, she was a woman empowered to spread the gospel and in the early days of LGBTI theology she was hailed as a transvestite, transgendered or transsexual but a queer eye asks if this motif of a cross dressing women was used to tell us something of significance about the relationship of people who become Christian with their gendered environment? Contemporary scholarship is no longer content to leave the argument that she and others cross dressed for the sake of safety. After all in 
Thecla's story she does not cross dress from the beginning even though she is travelling and at some risk, she only cross-dressed after baptism. An event in which she would have been told that in Christ there is neither male nor female since Gal, 3:28 was used as the text for baptism in those early days. She was entering a new form of life that upset the social order, no male no female, no slave or free, no Jew nor Greek, this was a world beyond the boundaries she would have known and asking her to navigate an entirely new way of being.

John Anson (1972, p. 1-32) has argued that cross dressing women such as Thecla were putting on the male form of Christ. There is perhaps another reading which is that she embraced the wholeness of God, clothed in the full gender richness of that divine reality. I wish to argue that women like Thecla understood their male attire as connected to overcoming the binary opposites of gender that set in place unequal lived reality. Cross dressing implies a starting point and a place towards which one is aiming and so serves to highlight gender polarity since clothes allow us to play with identity and they aid that becoming, they enable a physical embodied performance. Cross dressing creates an illusion for the user and the observer or, as Van Gennep puts it, it is a liminal space allowing movement across boundaries and transversing margins which confine (SUTHRELL, 2004, p. 18). Crossing dressing is an ingenious tool as it does not fit categories of sex or gender alone and as such exposes both and so in this way is a form of gender iconography' making visible the spaces of possibility which are closed off by dichotomous conceptualisation. Ritual cross dressing which predated Christian cross dressing has at its heart the notion of returning to wholeness believing that it allows a very deep experience of gender both one's own and the other. In some societies cross dressing represents magical qualities which is signalled by the ambiguity. So Christian cross dressing has a cultural heritage and in taking seriously the message of equality of the Christian gospel those who did it queered gender in order to find a way of living that radical equality rather than being primordial males. After all once we engage in confusing the categories it leads to 
their breakdown as oppositional points of reference and we need to ensure that we do not replace them with points along an old axis.

But is that all that is happening are the categories simply being confused or are they being erased? Liz Stuart (2009, p. 127-138) argues that the central sacrament of the Christian churches, the Eucharist, stands as an embodied practice suggesting erasure of gender and sex, it takes both she claims to a symbolic level and displaces them. By this sacramental enactment we move through a range of identities all of which become unstable and finally are erasured - so as a welcoming community the church gathered in this communal meal should never accept any identity as final. I embrace the notion of unstable identities but find I have difficulty with the idea of moving to a symbolic realm before total erasure this makes my feminist heart sink. The symbolic world which for Stuart is metaphysical has done no favours to any of us. It is the world in which Lacan tells us women and may I suggest even queers have no place since the symbolic is wholly and purely traditionally male and is conveyed through language and culture which according to him necessarily exclude women- why then would we see the symbolic as a powerful dwelling place for anyone who does not fit or does not wish to fit this fixed identity? Irigaray highlights this dilemma by suggesting that there can be no subjectivity until women find a place in culture since this belonging gives psychic leverage to our personhood (IRIGARAY apud HOWSON, 2005, p. 103). For Irigaray this can begin with the body. Braidotti (1994, p. 109) acknowledges that bodies can be radically subverting of culture when they find their voice beyond the fixed language and meaning of the masters discourses. This she suggests is to engage in a politics of positioning (BRAIDOTTI, 1994, p. 73) to find new ways of being by thinking through the body. Although these women were speaking about women the queerness of their suggestions can be seen and does raise the question of 'a voice' within fluid and boundary pushing identities -do we just have one voice or multiple voices with multiple subjectivities? A question I do not have an answer to but hope to engage with in a future project. 
Braidotti speaks of figurations which are politically informed accounts of alternative subjectivity. The living "as if' which is 'a technique of strategic relocation in order to rescue what we need of the past in order to trace paths of transformations of our lives here and now." She continues, "as if' is affirmation of fluid boundaries, practice of the intervals" which sees nothing as an end in itself (BRAIDOTTI, 1994, p. 6) - not even the Symbolic Order. For this reason then we need to be nomads, taking no position or identity as permanent but rather trespassing and transgressing, making coalitions and interconnections beyond boxes.

The nomadism of which Braidotti speaks perhaps enables theologians to pick up the notion of Christians as resurrection and pilgrim people especially in the light of our nomadic cross-dressing fore sisters. Should we take seriously the possibility of shifting and moving within gender and sexual identities that could free us from the oppressive repetitions required by religion, politics, economics and culture. Perhaps by highlighting the constructed nature of gender categories we begin to draw attention to their foolishness and restricting (non-redeemed) nature and begin to enflesh the Galatian baptismal formula, "In Christ there is neither male nor female" - is this a Christian politics of positioning and can it be argued that it is the very nature of incarnation itself - shifting, moving and permeable.

It is not only in these early years and the writings of women in the Apocryphal Acts that we find Christianity being at home within interesting gender and sexual enactments by its followers. Richard Rambuss (1998) has undertaken some interesting research in the area of erotic desire and the sacred within Christian history and what he has uncovered is the way in which the sacred erotic transgresses the boundaries of vanilla heterosexuality, that form of sexuality that is paradoxically upheld with such vigour by Christian morality and underpinned by Christian understandings of gender. Reading Rambuss we may agree with Michael 
Warner who says "religion makes available a language of ecstasy, a horizon of significance within which transgressions against the normal order of the world and the boundaries of self can be seen as good things". (WARNER apud RAMBUSS, 1998, p. 58). Is this language of ecstasy a linguistic site, as Braidotti would call it, a mother tongue through which people may begin to see queerly.

Rambuss takes us on a magical tour of religious devotion where the iconised body of Christ is the desirable object, this body becomes fully eroticised through the desire that those worshipping it direct towards it and receive from it. What is interesting for the present paper is that this iconised body of Christ is very changeable and does not in any way at all hold fast to or fixes sex, gender or sexuality either in itself or in those who adore it. Catherine of Sienna marries Christ who crosses genders for Catherine who eventually becomes engaged passionately with, sinking into the flesh of, a female Christ. Catherine is but one example of many littered throughout Christian history who engaged with the body of Christ only to experience a crossing of gender either for Christ or for themselves. Many writings and art works show the body of Christ as very fluid at times even appearing as physically female. In the sonnets of John Donne he implores God to ravish him, to batter his heart, to take him, break him, imprison him. These may appear to be rape fantasies but one must also not forget they are homosexual rape fantasies. Rambuss wonders whether in the work of Donne we see that redemption is sodomised or that sodomy has a place in redemption. Either way this religious and pious outpouring moves us beyond the edges of conventional morality. This theme of divine rape is carried on in the work of Traherne who in a poem entitled 'Love' imagines himself drenched in and impregnated by Christ's "sweet stream". He goes on to say that he offers himself to Christ as "His Ganymede! His Life! His joy!" whereupon Christ comes down to get him and takes him up that he may be "his boy" (RAMBUSS, 1998, p. 54). Rambuss (1998, p. 109) insists that closet devotion "is the technology by which the soul becomes a subject" a space in which the sacred may touch the transgressive and even the profane. In these brief examples we see a broader picture of Christian devotion than many would expect 
but is this queer theology since there is much gender crossing but it seems to be within the binaries?

One woman in our history who does not accept binary distinctions is Margery Kempe who places before us the embodiment of moving beyond otherness and who more than most illuminates Heyward's assertion that "our sensuality is the foundation of our authority" and may offer a queerer perspective (HEYWARD, 1989, p. 93). Margery Kempe gives us a graphic example of a woman who in her lifetime moved from the traditional to the very queer, changing economic and social circumstances as she went. From the confines of her birthing bed, on which she nearly lost her mind due to post-natal depression, she engaged with the person of Christ as a handsome and sexually desirable young man who spoke words of comfort and hope to her. This embodied encounter was the beginning of her revolution. It was the first of many intimate moments Margery would share with Jesus and God each leading to a greater assertion of her own being and bringing her closer to a full and free life.

Margery is a good example of how the fullness of eroticism triggered by an object of desire can lead to transgressive fullness within the sacred. Margery, weds God but this is still the Godhead who for her is father, son and spirit, who we should understand as female, with a very important addition - Margery herself, so she is marrying herself as well. We are boldly told that God himself declared to her "and God is in you and you are in him" (KEMPE, 2015, p. 81). Perhaps this in the context of such intimacy is the first queer move - the distance that has been so often felt necessary in Christian theology in order to inspire devotion as well as exert control is totally removed- it becomes difficult to know where or if there are any end points in God within this extraordinary relationship - God is expanded through Margery as much as vice versa.

This is a very extraordinary marriage, one that crosses all kinds of boundaries and opens up all kinds of possibilities, she has very passionate sex with 
God who is seen as her child while Jesus is both her husband and her son when they have sex- and of course the Godhead always remains female and involved. Everything is thrown into disarray and what emerges is a relationality based on radical subjectivity through which Margery's self becomes bigger. Her vision of being wedded to and an integral part of the Godhead enable her to experience heredges as expanded but at the same time she moves around her own core in a dance of autoerotic/erotic self discovery. The nomad in her experiencing Margery the father, Margery the son, Margery the spirit at the same time as embracing father, son and spirit [female] as wedded lover. Of course, in this mutual subjectivity father, son and spirit all experience their divinity through Margery. Subjectivity is heightened the more identity becomes nomadic but this is no mere gender performance - father, son and spirit are all interchangeable and as such go beyond gender categories and into animal, mineral, ether, bread, wine, presence and absence and so much more. This is a subjectivity with no edges, a contradiction, a boundarylessness that gives meaning but fixes nothing. Margery is released into a fuller life through changing "the subject" and she expands the boundaries of theology by being so liberated. She propels us to explore limitless embodiment and radical subjectivity and in so doing to truly incarnate the gospel of radical equality. Reflecting on her life we may begin to speculate that while we continue to allow the enactment of fixed binary opposites, stable and unequal categories on our bodies through sexual stereotyping or sexual intimacy we fail to open to the diverse/surprising wonder of radical incarnation. I would suggest that Margery challenges our very acts of intimacy and by observing her sexual freedom with the divine we might even be pushed to suggest that fucking straight or fucking queer questions our entire theology and the world we dare to hope for and live towards. In a real sense private acts of intimacy create our world - they draw us into the social and the politics embedded in it. 


\section{Reading Scripture Queerly}

We appear to have a history then that bears fruit under feminist and LGBTI enquiry and I would suggest even Q. Does this mean that Christianity is/has always been queer or just that certain individuals in it have queered it? Graham Ward (2004, p. 71-85) of course would claim that the gospel tells queer stories in the sense that what we have conveyed as salvation history involves a number of queer moves and displacements. Ward argues that from the outset the male body of Jesus is peculiar, for a start it springs solely from the body of his mother and sois materially unstable; even if virgin birth were possible parthenogenesis would result in a female child. I do not actually wish to claim that Jesus was a physical virgin birth but I find more queer milegage in the suggestion than Ward does. I think we queer the body of Christ, understood as baby and church, by placing its entry into the world through the real vaginal canal of the real woman Mary. In so doing we wipe aside the clean and tidy metaphysics of the sanctuary that held Jesus and place him in the womb to be propelled into waiting arms amongst the blood, sweat, tearing, shit and weeping of a real birth. Born to a mother who may have been raped, who was certainly too young and who lived under occupation. This story is in my view queer because this 'quite wrong mother' had a virgins womb, that is to say whatever the circumstances of the conception her child came from behind a protective hymen not as the product of a phallic colonisation but as a child of a wild and free woman. As we have no way of knowing the true circumstances it seems to me that this telling is as challenging as any!

Ward argues that right from the start materiality is becoming metaphorical and this is expanded throughout the gospel accounts where the man walks on water, is transfigured, ascends bodily into heaven and is said to be present in the breaking of bread. In each of these scenarios the body of Jesus is displaced and, according to Ward, the sexed body becomes problematized and eroticised. Ward suggests that the gendered body of Jesus is malleable and capable of transposition and that the gospels chart this course of increasing destabilisation and many 
transformations. Each of these makes manifest more of the divine glory and the important point to notice, for Ward, is that it is not the gendered body that does this but the body that demonstrates how these boundaries can be pushed. He wonders if some queer theology does not push hard enough perhaps just reproducing fashionable bodies and adding them to the theological mix. This I think is a good challenge and one to be kept in mind when engaging in queer theology. Ward offers a lot to the discipline as he does not only challenge gender but corporeality itself noting that the gospels see no limits for it (WARD, 2004, p. 83).

We also know that much devotional art follows a queer road reflecting as it does many of the foundational moments of Christianity. For example, we see in Renaissance art, which was theologically underpinned, that the Christ child is both baby and spouse and he inseminates his own mother. In a Holy Family representation by Hans Baldung Grien [1511] we see “Jesus" grandmother very publicly and deliberately fondling his penis. The child, in turn, is touching the chin of his mother while Joseph looks on having laid his book to one side. This is strange indeed to the untutored eye but it is actually alive with theology. It is through Anne that Jesus' human lineage is guaranteed and so she is the one displaying it to the world in an extremely physical way. Scholars suggest that the touch of the chin is no innocent baby gesture it is a highly charged erotic gesture and so in this context is suggesting that the baby Jesus as the Heavenly Bridegroom is choosing his mother to be his eternal consort. It is interesting to me that even in this highly theologically traditional image it is the women who are making the incarnation both possible and known. In pictures of the ascension of Christ we note God fondling his son's penis and in yet others he appears to be anally penetrating his Son - art historians tell us these images signal the completion of salvation for humanity, which we can only find interesting! What we know is they were all based on theology of the time and so seem to signal a set of displacements of what might be called human/divine norms. The body of Jesus is also often depicted as female; Christ is understood to lactate, to offer his breast as food and to possess a womb into which believers may enter for rest. Caroline 
Walker Bynum (1991, p. 102) believes that the theology of the period wished to emphasis the role of Jesus as mediator in joining our substance to divinity at a time when Mary was understood as the flesh of Christ. This has profound implications for queer theology. Bynum is suggesting that the representations of the body of Christ can be seen as moments of symbolic reversal in which role and status are overturned and normal structures thrown to the wind. She says this is nowhere clearer than in the Eucharist where what a woman is supposed to be is publicly inverted. Christ on the cross and offered in the Mass did not and does not become a King but rather a lactating and birthing mother. So we see that the notion of the instability of gender and sex is not a new thing in Christian theology it has been there all along. Does this tell us that the very heart of Christianity is queer? That is, unstable, flexible and challenging.

Well it is one thing to read Christian history in a queer way since after all we can rewrite the master narrative for ourselves but what happens when we come up against doctrine, that part of Church life that is believed to be unchangeable as it expresses the very nature of God?

\section{Doctrine Through a Queer Lense}

Marcella Althaus-Reid is just one of the people who requires theologians to face the full reality of people's lives when expounding doctrine. She argues that a new understanding of Christ is needed one that moves away from 'the Christ' who is the fetish of Christianity and the patriarchal discourse that underpins it. She develops the notion of the BI-Christ, a figure who is not bi in the sense of sexual preference but rather in terms of thought and life, is one who is fluid and full of contradictions and therefore enables the destabilisation which she saw as crucial. She argued that the Bi-Christ is in fact, a gospel image pointing out that the gospels present us with the Prince of Peace and the one who whips the traders from the temple, the one who talked to the women at the well and could not 
change the impurity laws regarding menstruation. When we take these stories as starting points we go in contradictory directions but far from wishing to harmonise these points of tension Althaus-Reid wants us to embrace them as the fluid movements of incarnation /Christology (ALTHAUS-REID, 2003, p. 112). Taking the evidence before us and asking the challenging questions allows the false harmonising to be stripped away and a new and exciting rupture to emerge. One that Althaus-Reid says is beyond the hetero - Christ, that is, the Christ of deeply engrained clear and limited boundaries, the Christ of power over and hierarchies, the Christ of deadening dualism. The Bi-Christ is beyond either/or, this is the Christ of liberation theology who liberates the poor and the rich from structures of oppression but not into one unified and harmonious liberation, rather into very different outcomes from diverse starting points (ALTHAUS-REID, 2003, p. 114).

As a theological category the Bi-Christ overcomes mono-relations and this has an impact in sexuality and beyond. Althaus-Reid gives illuminating examples of how the mono-relational pattern works. Firstly, the hetero-Christ even defines sexual relations that are not heterosexual, the gay man is seen as effeminate and the lesbian as either butch or femme. These are heteronormative categories that prohibit naming the diverse range of sexual identities (ALTHAUS-REID, 2003, p. 116) that are actually operational within people's lives. Heteronormativity stabilises categories and colonises experience in order to keep some control, if only through ostracising. The second example is of how mono-relations lead to economic oppression. Using the colonisation of Africa as an example, AlthausReid points out that the relationship under one [mono] heavenly Father could never be equal- that father was not flexible enough. The exclusion of "otherness" meant that needs, desires of the other do not enter the equation and exploitation steps in. Althaus-Reid argued that the Bi-Christ dismantles the mono-relations of naming, organising, exploiting and owning that underpin economic, racial and sexual exclusions and the worlds this leads to. Bi-Christ allows other ways to think. By using the lived experience of women and girls in the creation of an indecent theology one based in the pleasures and pains of female sexuality is Marcella assuming essentialism here that clashes with queer understandings of sex and 
gender - well yes and no! Marcella was angry with liberation theology and by extension with some feminist theology which she felt romanticised and even sanitised the lived reality of women and men particularly in the area of sexuality and gender and it was this that moved her to what she understood as indecent and queer theology. Indecent because she did not just bring the 'nice' experiences, the holy experiences to the creation of Christology and Queer because in examining real lives, categories will just not do, boxes are just too small and all kinds of crossing over becomes necessary in order to grasp something of the reality we experience within and between us. By examining the dialectics of decency and indecency and exploring a theology of sexual stories from the margins AlthausReid brings to light and problematizes the oppressive layers of perceived reality theological, political and amatory. Indecent theology challenges the creation of a factual sexual order, an order Althaus-Reid suggests that underpins all theology with its patriarchal roots. Indecent theologians are those who are sexual performers of the praxis of social justice and transformers of structures of economic and sexual oppression. But perhaps then even the Bi-Christ is not queer enough unless we hold on to the not either or of its construction. It may not be far enough but it is a step beyond where most feminist theologies had gone.

Perhaps the image that Althaus-Reid places before us that caused her most trouble is in many ways the most queer, not simply by appearance but because the image turns central doctrine on its head. Althaus-Reid asks what implications there would be if we placed a leather women on the cross; Xena warrior Christ ${ }^{2}$. She does not hang there asking that people be forgiven, she yells and curses vividly describing what she would do to her oppressors if she could get her hands on them. Here is a woman with a strong sense of her own sexual identity which she has created herself. In addition she is no passive victim, she is a warrior and one who loves women. This is a queer image not only because it is sexual but because it combines leather women with spirituality. There is a dramatic clash between

\footnotetext{
${ }^{2}$ Marcella takes this image from a comic strip entitled, Xena, Warrior Princess (WAGNER et al., 1999).
} 
sexual and gender identities and classic spirituality. This is not a Christ we can easily recognise and this is just the point, we are required to shake up all preconceived ideas and think again. Christ is gender fucked and we are awakened to new thought processes and ways to respond. What does it mean if God is this aggressive, warrior woman who will fight to the end for the one she loves but ultimately in her last breath declares she cannot even save the one she loves? I am left wondering if it was the leather, the aggression or the inability to save even her loved one that has disturbed people the most.

There have been many queer readings of scripture as we know and far too many to deal with in this paper so a couple will have to suffice. I particularly enjoy Ken Stone's reading of Jeremiah (STONE, 2005) in which he finds the prophet to be a very 'sassy bottom' giving God, his daddy, a very hard time. What is interesting about this reading is not just the mere suggestion that the relationship between God and the prophet may be a sexual SM one but the very nature of that relationship. Here is a reversal of what might be expected, the apparently dominated one actually having the upper hand. In reading from marginal experience Stone has allowed the possibility for other readers to reflect on their relationship with God, perhaps no longer the submissive worshipper but the subject who can argue back and have ideas of their own, who can legitimately give God a very hard time. Stone's reading is no longer simply one that includes marginalised groups but opens up the text for a wider audience.

My own attempt at queering texts came when exploring the nature of celibacy as traditionally understood by the Catholic Church (ISHERWOOD, 2006). It is believed that celibacy has its biblical base in the Song of Songs which is actually the most erotic text in the whole canon. Tradition, of course, neutralised the eroticism through dualistic thinking before it was used as a base for celibacy, the Bride of Christ longing for chaste union with Christ took the place of the passionate lovers who loved beyond the boundaries of their society. This mystical marriage that was advocated by those such as Bernard of Clairvaux attempted to veil the true eroticism of this text. What a tragic disservice Greek metaphysics have 
done to the Christian tradition. However we only have to return to the text itself to see that it does not carry even the notion of marriage let alone a mystical union and interestingly does not mention God at all.

What we read is of two lovers of different races meeting with disapproval from people in both communities and families. She is black, 'I am very black' [Song of Songs 1:5] and this offends the daughters of Jerusalem who would have this man for themselves, not transgression of racial lines are to be tolerated. Her brothers are offended because she gives herself freely to her lover beyond the legal contract, the 'knowing' of marriage. ${ }^{3}$ In this way she diminishes her worth as a family asset, she will not actually be able to make a good marriage after such an affair. And their passion for one another is not linked at all to procreation, simply to attraction, beauty beyond the normal bounds of the acceptable face of attraction and pleasure. The text abounds with references to the non-penetrative nature of much of their love making and the pure delight that they both experience in this. The woman here is no simple object she is also a subject of her own desire. There is no mention that theirs will be a marriage as they are engulfed in the moment and absorbed in each other's pleasure. It is very exciting that such a text has formed the basis of Christian ideas of celibacy! These two are clearly unmarried but it gets a little queerer since the woman wishes that her lover was her brother and if he was she would lead him into the house of their mother where she would give him "the juice of my pomegranates." [8:2] There are echoes here of Margery Kempe who in the heat of her passion with Christ placed before us potentially queer family relationships, human as well as divine. In this verse the woman is longing for a space in which they can be outside the censure of the society in which they live, as her brother she could kiss him and no one would notice but clearly in the house of their mother she would go further. Within her context what is obviously being challenged is the father's household since in the house of their mother even incest seems not to be beyond limits. This of course draws us to examine the strict

\footnotetext{
${ }^{3}$ To know was a phase to do with the legal part of a marriage rather than the sexual part.
} 
relations between the patriarch and his family, he would own her and his son would be guilty of trespass and theft if he slept with her. The patriarch may of course sleep with his daughter but the young male may not - in their passion the woman of this Song is transgressing the boundaries even of the patriarchal household. By returning to the mother's house the woman envisions a turning on its head of the patriarchal order. She further throws queer potential on this sexual arrangement by declaring, "this is my beloved and this is my friend" [5:16] not a relationship that would have been evident in patriarchal marriage of the day. Texts may be queered when we move beyond the expected and predicted readings laid down by church tradition. In my engagement with this particular text I found that all kinds of categories could be queered from race, to sex, to patriarchy itself and within that even the notion of incest. The text may suggest that when carried out in a patriarchal context incest is about ownership and domination but the woman in the text wishes to take the man as her brother to her bed, boundaries are crossed just as in Margery Kempe's relationship with Jesus, son, lover, husband, father. What seems to come to the fore here is not so much the sexual activity itself but rather the fluid boundaries of familial relations which would not have been the norm in the time of either the Song of Songs or Margery Kempe. There is a very significant queering here that includes human and divine relationality.

But perhaps it is worth keeping in mind that readings from the life of marginalised communities and persons that have shed new light on the divine human relationship and given a voice to those who have hitherto simply been condemned by the readings of scripture by others. In addition, we should also remember that the canon of scripture was made by people in support of their witness to God in their communities - perhaps the "truth" of scripture hangs on that alone- if this is the case then queer myth making is both needed and legitimate. And from this perhaps ethics/practices of sex, gender, economics, ecology and race and much more will emerge differently- and nomadically. 


\section{Queer Theology and the Mono God}

I think it can be argued then that there is a fluid rupturing core in Christianity, even in scripture and doctrine, a queerness that begs to be embraced. Why then do the wheels of Church and theology grind on in the repetition of endless binary thinking? This brings us to the biggest challenge that the multiplicity of queer theology offers Christianity. Irigaray perhaps sums it up neatly when she says "One betrays ones naiveté if one considers our modern societies to be simply patrilinear...or capitalist... and ignores the fact that they are at the same time governed by monotheism." (IRIGARAY apud KRITEVA, 1974, p. 19-20). Have we theologians been naive if we feel we can keep monotheistic thinking which has underpinned many of the damaging elements in our heritage and engage fully with incarnation and its queer living?

Of course not all theologians even those who understand the damage done by monotheistic thinking wish to abandon it entirely. Mayra Rivera approaches the doctrine through a postcolonial theology of God speaks of the touch of transcendence. Right from the start she makes her position plain: God is beyond our grasp but not beyond our touch just as we find that in human touch we touch, but can never fully grasp, the other, creating what she suggests is a "intimacy of transcendence" (RIVERA, 2007, p. 2). Situated as her argument is in postcolonial theology she demonstrates how the dominant imperial theology of the West has never acknowledged anything beyond itself. While using the disembodied nature of the ONE God to set in place the Western masculinist symbolic, at the same time it stops the world, both physical and symbolic, at its own narrow vistas. Rivera of course is also aware that falling into the untouchable, vertical transcendence that usually follows on is no place to go for those who sit beyond the vista of the western mind, those who have not been seen or acknowledged as inhabiting land and ways of life that fall beyond. It is precisely because of this that she sees the need for a form of transcendent theology that breaks down the western stranglehold. For her there is nothing abstract about transcendence as in the hands 
of the powerful it even controls the creation of time and our spatial perceptions. Her argument is that western industrialism needed to move beyond the rhythms of natural time and impose a universal time in order to maximize the profits it wished to extract and to disconnect people from their land and their natural ways of being. This also separated the public and private sphere with the private time being seen as feminized and trivial while public time was of the greatest importance, the masculinised time of uninhibited production and detached transcendence (RIVERA, 2007, p. 8). She argues that horizontal transcendence has divided space itself with what is north as being understood as closer to God while the south is nearer the depths of stagnation and even depravity. She believes that such overarching systems of knowledge produce rather than discover all-encompassing foundations, they create the illusion of totality. Rivera does not wish to go as far as the elimination of transcendence but rather to refuse to understand it as identifying God with the status quo.

She understands transcendence to be in history because if we see God as external then the liberation claim that salvation lies in a re-making of history, undoing injustice and replacing it with inclusive and just systems in the here and now, is a false hope and an empty theology. It is the possibilities lying in the living of history in the material body that allows for the great hope of human kind, things may happen that have never happened before, "newness is not just discovered as being already present in nature, nor is it externally imposed upon reality. Genuinely new things come into existence from the actualisation of possibilities through collective choice." (RIVERA, 2007, p. 43). Rivera claims that this notion of historical transcendence is dynamic, allowing for contextual structural difference without implying dualism, and for intrinsic unity without strict identity categories imposed.

Laurel Schneider (2008, p. 192) admires the work of Rivera but is not persuaded by the argument she believes that within the logic of the ONE there can be no room for multiplicity and one may even argue diversity. For her the choice is clear do we settle for the world of categories and abstractions that the ONE 
presents us with or do we embrace what she calls the multiplicity which is the diverse nature of embodiment. An embodiment that refuses categories since bodies do not tend to come in rigid categories with one set of identity marks and ways of being in the world. Schneider points out that a fundamental goal of love and peace cannot be satisfied under the regime of the ONE. In accordance with other feminist theologians she suggests that love needs another, it cannot be without encounter and it cannot be ethical unless it recognises the presence of others as they are. Heyward spoke powerfully of this saying that it was the desire to love and be loved that drew the divine from the heavens and into relation through incarnation. It was God's desire to love and be loved that brought about this outpouring and it is the continued desire that means the divine will never retreat to the heavens and the place of Absolute Oneness, in such a move all relation is lost, all possibility of loving and being loved. For Schneider this way of seeing things signals a notion of the divine so based in love that it is willing to show up and fully risk, nothing less will do (SCHNEIDER, 2008, p. 206). It is this and this alone that changes things. Schneider speaks plainly when she says, "to follow God who became flesh is to make room for more than One it is a posture of openness to the world as it comes to us, of loving the discordant, plentipotential worlds more than the desire to overcome, to colonise or even to 'same' them." (SCHNEIDER, 2008, p. 207). Laurel is not alone in her desire to derail the ONE - the mono of divinity - as we saw, Marcella was also aware of the dangers of mono thinking and in my work from an incarnational standpoint and I have been pushing at that concept for some time via notions of radical incarnation, the total abandonment of the divine into flesh (ISHERWOOD, 1999) which even places that aspect we have called transcendent within and especially between people. In what ways can queer theologians shift this concept of monotheism in order to open up the next step in the journey?

I have found that Catherine Keller furthers the struggle as she enables us to move from monotheism through an investigation of the Deep which is the very ground of who we are but as we shall see it is no fixed identity relying on the ONE. 
It is a Deep situated in the cosmos itself that gives the lie to creatio ex nihilio and opens before us the God who is of intimate/infinite entanglements. The God who is the All in All of Corinthians, not beyond, not distant but entangled. Keller visits Paul's writings in 1 Corinthians on the body of Christ and reminds us that in the Greek energeia is used in 12:4-6 when he tells us that there are differences but it isthe same God who is in all (KELLER, 2012, p. 11-25). For Keller this disables any theology of distance and separation God is not above, nor is the divine simply androcentric but rather the very bible itself declares God to be eco-centric, All in All. Energy then is not something we have but something we are (p. 12) and it is the same energy that gives life to everything it is the stuff of entanglement. Keller writes, "feeling the pulsations of our bodies in our planet and the pulsations of the planet in its universe our earthly interactions are rendered simultaneously intimate and virtually infinite." (p. 13). This is the energy of eternal delight which comes from the free flow of these energies uninhibited by repression, exploitation and denial. One may add and uninhibited by a desire to see distinctions between this energy and God. Just as Heyward before her accused theology of making us less than we are by dampening and denying desire within us so Keller suggests that exploitation and denial of divine entanglement blocks energy which leads to depression and lack of meaning.

Keller throws us back to cosmic beginnings, to void and chaos, to understand who we are and who we might be from tohu vabohu, the depth veiled in darkness. Once we give agency to void and chaos creation out of nothing as our power laden dualistic origin crumbles and creation ceases to be a unilateral act. Keller tells us that 'let there be' in the pages of Genesis become a whisper of desire, not a command, drawing forth all that already is rather than drawing down 'being' from above and beyond. In this shift incarnation is understood as the rule rather than exception in all of creation. Importantly, incarnation emerging from chaos and its endless possibilities for all that lives and not as a 'fixing agent' placing all things in their place from the beginning. There may be echoes here of Rivera but for Keller the vista is much wider than human history, it is cosmic. 
I understand Keller's reworking of origins as radical incarnation, that is taking incarnation seriously without the comfort of metaphysics, delayed parousias and absolute Godheads, an understanding that is key to our living this profound reality. This is an understanding of incarnation based in empowerment and the shared human/non-human heritage of dunamis, that raw energy which attracts us to the world and all that is in it. This is the concept spoken of by Jesus in the gospels when he rejects "authority over" and urges those who come after him toclaim their empowerment to live in vulnerability, mutuality and relationality. It is an empowerment that is increased in the free sharing between equals. This power of incarnation can also be argued to be the wild, dynamic and empowering core that moves us closer to an understanding of radical otherness, that is the divine/human, divine/non-human nature of all that lives.

If we have the possibility of understanding incarnation as that which enables us to live in the world rather than imagining that our true home is elsewhere away from the rest of the material world including our non-human coinhabitants, then we have to keep asking what it means to be alive and embedded in radical incarnation.

The nub of the issue for the future of queer theology seems to be what to do with the ultimate edge, the end point, the unchanging all powerful God within a form of theology that is always moving beyond, expanding, displacing and unsettling? Laurel Schneider is quite clear that we have to get rid of "monotheistic eschatologies that fantasize the end of all difference in the truth of God" (SCHNEIDER, 2008, p. 73). I believe that if we wish to move from queering theology to having truly queer Christianity then tackling the mono divine in our traditions is the next step. It is my fervent hope that queer theory aids theology in the task of moving from metaphysics to metamorphing, not just for the sake of it, but in order that more space may be made for the glorious and diverse divine to dance and /be celebrate/d. My word of caution would be that we do not believe 
that 'queer' is the label that solves all problems - perhaps this is my feminist liberation heart speaking- but I think we should always be mindful that even as a flexible, boundary pushing word it can also hide many of the political issues that still exist around race, economic status and even gender. If we simply abandon the categories without first having thoroughly investigated them and understood how deeply they affect society and our psyches then in my view we will just repeat the mistakes and live the oppressions under other names. As Jay Johnson has noted (JOHNSON, 2013, p. 6), even though he writes from a queer perspective he is atthe end of the day a white, privileged male who can in large part avoid the worst of outcasting and oppression in society. Of course the identity politics of my youth also prompt me to ask whether such destabilising of identities comes with loss of political clout that group identity carried with it. My hope is that queer cosmic theologies will move us beyond that particular set of labels and into a more embedded sense of being- one built on volatile ruptures and earthquakes- which allows us to embrace glorious risk in the every unfolding, flaring and spiralling of endless possibilities through moments of touch and recognition that are our true home.

\section{Conclusion}

This paper has attempted to show that the rigid way in which Christianity has been presented throughout its history is far from its truly queer heart, a heart that beats through multiple displacements of materiality. It also highlights that there have been individuals and moments within Christian history that have moved beyond the understandings of their contexts and offered new and unexpected opportunities for the bursting in of new visions of reality that hols within them greater opportunities for flourishing, for the expansion of the divine/human. Through an embrace of the new cosmology and insights regarding incarnation I have suggested it may be possible to move beyond what has been an obstacle to what I understand as freely queer Christianity and that is monotheism 
and the all-encompassing ONE. The One who makes the multiplicity that incarnation implies absolutely impossible. Tackling the implications of this move perhaps forms part of a queer future for theologians who work within a Christian frame.

\section{REFERENCES}

ALTHAUS-REID, Marcella. The Queer God. London: Routledge, 2003.

ALTHAUS-REID, Marcella; ISHERWOOD, Lisa (ed). The Sexual Theologian: Essays on Sex, God \& Politics. London: T\&T Clark, 2004.

ANSON, John. The Female Transvestite in Early Monasticism: The Origin and Development of a Motif. Viator: Medieval and Renaissance Studies, Berkeley, n. 5, p. 132, 1972.

BRAIDOTTI, Rosi. Nomadic Subjects: Embodiment and Sexual Difference in Contemporary Feminist Theory. New York: Columbia Press, 1994.

BYNUM, Caroline Walker. Fragmentation \& Redemption: Essays on Gender and the Human Body in Medieval Religion. New York: Zed Books, 1991.

HEYWARD, Carter. Touching Our Strength. The Erotic as Power and the Love of God. San Francisco: Harper Collins, 1989.

ISHERWOOD, Lisa. Liberating Christ. Ohio: Pilgrim Press, 1999.

ISHERWOOD, Lisa. The Power of Erotic Celibacy: Queering Heteropatriarchy. London: T\&T Clark, 2006.

JOHNSON, Jay. Divine Communion: A Eucharistic Theology of Sexual Intimacy. New York: Seabury Books, 2013.

KELLER, Catherine. The Energy We Are: A Meditation in Seven Pulsations. In: BOWMAN, Donna; CROCKETT, Clayton (ed.). Cosmology, Ecology and the Energy of God. New York, Fordham University Press, 2012. p. 11-25.

KEMPE, M. The Book of Margery Kempe. Trans. Anthony Bale. Oxford: Oxford University Press, 2015. Chapter 35.

KRISTEVA, Julia. About Chinese Women. Translated Anita Barrows. New York: Boyars, 1974 .

Horizonte, Belo Horizonte, v. 13, n. 39, p.1345-1374, July/Sept. 2015 - ISSN 2175-5841 
MACDONALD, Dennis. The Legend and the Apostles: The Battle for Paul in story and canon. Philadelphia: Westminster Press, 1983.

RAMBUSS, Richard. Closet Devotions. Durham: Duke University Press, 1998.

RIVERA, Mayra. The Touch of Transcendence: A Postcolonial Theology of God. London: WJK, 2007.

SCHNEIDER, Laurel. Beyond Monotheism: A Theology of Multiplicity. London: Routledge, 2008.

STONE, Ken. Practising safer texts: food, sex and Bible in queer perspective. London: T\&T Clark, 2005.

STUART, Elizabeth. The Priest at the Altar: The Eucharistic Erasure of Sex. In: ISHERWOOD, Lisa; Althaus-Reid, Marcella. (ed.). Trans/formations. London: SCM, 2009. p. 127-138.

SUTHRELL, Charlotte. Unzipping Gender, Sex, Cross Dressing and Culture. Oxford: Berg, 2004.

WAGNER, John; CHIN, Joyce; WONG, Waldon. Xena, Warrior Princess. Milwaukee: Dark Horse Comic Inc, September, 1999.

WARD, Graham. On the Politics of Embodiment and the Mystery of All Flesh. In: ALTHAUS-REID, Marcella; ISHERWOOD, Lisa. The Sexual Theologian: Essays on God, Sex and Politics. London: T\&T Clark, 2004. p. 71-85. 